\title{
PENERAPAN METODE TRUE OR FALSE UNTUK MENINGKATKAN HASIL BELAJAR MATEMATIKA SISWA KELAS VIII.7 SMP NEGERI 21 PEKANBARU
}

\author{
Rosnah \\ SMP Negeri 21 Pekanbaru \\ e-mail: rosnah1963@gmail.com
}

\begin{abstract}
the Activity of this Service is a downstream Research which was motivated by the low learning outcomes of students of Class VIII.7 SMP Negeri 21 Pekanbaru. This study aims to improve the learning outcomes of mathematics through the application of the true or false method of students of Class VIII.7 SMP Negeri 21 Pekanbaru, which is held for 1 month. As Subjects in this study are students of Class VIII.7 SMP Negeri 21 Pekanbaru. The number of students who made the subject of research as many as 39 students. The form of research is classroom action research. The instrument of this research consisted of learning result instrument and data collection instrument in the form of observation sheet of teacher activity and student activity.

Based on the results of research and discussion, the application of True or False method can improve student learning outcomes of grade VIII.7 SMP Negeri 21 Pekanbaru. Teacher activity in cycle I got score 35 with perfect category while in cycle II got to score 49 with the perfect category. Student activity on cycle I got score 226 with high category while in cycle II got score 309 with the very high category. Students' learning outcomes in cycle I got an average of 72.6 with high category whereas in cycle II got an average of 85.1 with a very high category. In cycle I this has not been said complete while in cycle II research has been completed or succeed with $100 \%$ success indicator exceed indicator of performance which has been set that is $75 \%$.
\end{abstract}

Keyword: True or false method, Mathematics learning result

\section{Abstrak}

Kegiatan Pengabdiian ini merupakan hilirisasi Penelitian Yang dilatarbelakangi oleh rendahnya hasil belajar matematika siswa Kelas VIII.7 SMP Negeri 21 Pekanbaru. Penelitian ini bertujuan untuk meningkatkan hasil belajar matematika melalui penerapan metode true or false siswa Kelas VIII.7 SMP Negeri 21 Pekanbaru, yang dilaksanakan selama 1 bulan. Sebagai Subjek dalam Penelitian ini adalah siswa Kelas VIII.7 SMP Negeri 21 Pekanbaru. Jumlah siswa yang dijadikan subjek penelitian sebanyak 39 orang siswa. Bentuk penelitian adalah penelitian tindakan kelas. Instrumen penelitian ini terdiri dari instrumen hasil belajar dan instrumen pengumpulan data berupa lembar observasi aktivitas guru dan aktivitas siswa.

Berdasarkan hasil penelitian dan pembahasan, maka penerapan metode True or False dapat meningkatkan hasil belajar siswa kelas VIII.7 SMP Negeri 21 Pekanbaru. Aktivitas guru pada siklus I mendapat skor 35 dengan kategori sempurna sedangkan pada siklus II mendapat skor 49 dengan kategori sangat sempurna. Aktivitas siswa pada siklus I mendapat skor 226 dengan kategori tinggi sedangkan pada siklus II mendapat skor 309 dengan kategori sangat tinggi. Hasil belajar siswa pada siklus I mendapat rata-rata 72.6 dengan kategori tinggi sedangkan pada siklus II mendapat rata-rata 85.1 dengan kategori sangat tinggi. Pada siklus I ini belum dikatakan tuntas sedangkan pada siklus II penelitian telah tuntas atau berhasil dengan indikator keberhasilan 100\% melebihi indikator kinerja yang telah ditetapkan yaitu $75 \%$.

Kata kunci : Metode true or false, Basil Belajar Matematika 


\section{PENDAHULUAN}

Kemampuan siswa dalam menerima dan mempraktekkan hasil pembelajaran merupakan salah satu unsur untuk mencapai keberhasilan yang maksimal dalam proses pembelajaran. Guru sebagai pelaksana langsung di lapangan mempunyai peranan sentral untuk menentukan keberhasilan pendidikan. Inti dari semua itu adalah terjadinya proses interaksi antara guru dengan murid dalam sebuah kegiatan yang dinamakan proses pembelajaran. Oleh karena itu mengajar merupakan suatu rangkaian kegiatan penyampaian bahan pelajaran kepada murid agar dapat menerima, menanggapi, menguasai dan mengembangkan bahan pelajaran tersebut.

Selama ini peserta didik menerima pembelajaran matematika tanpa pernah menanyakan mengapa dan untuk apa kita belajar matematika. Sering juga muncul anggapan bahwa matematika adalah pelajaran menakutkan, dan membosankan. Hal lain yang juga mempengaruhi rasa bosan pada pembelajaran matematika adalah faktor penyampaian yang dilakukan guru di sekolah tempat peneliti bertugas tidak kreatif dan monoton. Sehingga hasil belajar yang diraih peserta didik juga tidak maksimal.

Untuk mengatasi ketakutan dan kebosanan serta kurangnya semangat belajar peserta didik, perlu dicari metode atau model pembelajaran yang menyenangkan dan tidak membosankan sehingga dapat meningkatkan semangat belajar sekaligus mempermudah pemahaman peserta didik dalam belajar metematika. Salah satu metode pembelajaran yang saat ini dilaksanakan adalah metode Pembelajaran Matematika Realistik (PMR). Pendekatan Matematika Realistik (PMR) ini sesuai dengan metode pembelajaran saat ini, yaitu perubahan metode pembelajaran yang berpusat pada guru menjadi metode pembelajaran yang berpusat pada peserta didik. Hal ini adalah usaha dalam memperbaiki mutu pendidikan matematika.

Gerlach dan Ely (1980), menjelaskan bahwa strategi pembelajaran merupakan cara-cara yang dipilih untuk menyampaikan metode pembelajaran dalam lingkungan tertentu. Selanjutnya dijabarkan oleh mereka bahwa strategi pembelajaran yang dimaksud meliputi ruang lingkup dan urutan kegiatan pembelajaran yang memberikan pangalaman belajar peserta didik (Uno, 2011).

Matematika sebagai salah satu pelajaran yang sangat penting dikuasai oleh peserta didik atau karena matematika dapat meningkatkan pengetahuan peserta didik dalam berfikir logis, rasional, kritis, cerdas, tangkas serta kreatif. Oleh karena itu, pengetahuan matematika harus dikuasai sedini mungkin oleh peserta didik.

Kebanyakan proses pembelajaran yang digunakan oleh guru adalah pembelajaran konvensional yakni ceramah, tanya jawab, dan pemberian tugas. Dalam hal ini, proses pembelajaran dikuasai oleh guru. Oleh sebab itu harus segera diubah untuk mendapatkan hasil belajar (prestasi) yang memuaskan

Dalam rangka pencapain hasil pembelajaran yang maksimal dan tercapainya standar kompetensi perlu upaya-upaya terencana dan kongkrit berupa kegiatan pembelajaran bagi siswa. Kegiatan ini harus dirancang sedemikian sehingga mampu mengembangkan kompetensi, baik ranah kognitif, efektif, maupun psikomotorik. Karena itu, keahlian guru dalam memilih model pembelajaran yang sesuai dengan standar kompetensi yang akan dicapai, strategi pembelajaran yang berpusat pada siswa, dan penciptaan suasana belajar yang menyenangkan sangat diperlukan.

Berdasarkan pengalaman selama penulis mengajar di kelas VIII.7 SMP Negeri 21 Pekanbaru ditemui gejala-gejala atau fenomena khususnya pada pelajaran Matematika sebagai berikut: 1) Hasil belajar yang diperoleh siswa belum optimal, hal ini terlihat dari hasil evaluasi, 2) Siswa terkesan sulit memahami materi yang disampaikan oleh guru di kelas, 3) Kurangnya keinginan siswa dalam menjawab pertanyaan guru, ataupun mengajukan pertanyaan ketika pembelajaran di kelas.

Dari fenomena-fenomena atau gejala-gejala tersebut di atas, terlihat bahwa hasil belajar Matematika yang diperoleh siswa belum optimal. Keadaan ini dipengaruhi oleh cara mengajar guru yang kurang menarik perhatian siswa. Dimana guru hanya mempergunakan metode-metode konvensional seperti ceramah, penugasan ataupun tanya jawab sehingga siswa cenderung menjadi pasif.

Faktor yang mempengaruhi hasil belajar dapat dibagi menjadi dua faktor yaitu faktor internal dan eksternal. Faktor internal yaitu yang berasal dari dalam diri siswa. Faktor eksternal yaitu faktor yang berasal dari luar diri siswa. Salah satu faktor eksternal yang mempengaruhi hasil belajar siswa adalah cara mengajar/ metode guru dalam menyampaikan materi pelajaran kepada siswa. Berdasarkan 
kenyataan menunjukkan bahwa cara mengajar guru di kelas cenderung hanya menggunakan cara-cara klasik seperti ceramah ataupun tanya jawab, sehingga siswa cenderung menjadi pasif dan kurang semangat belajarnya. Hal ini dapat menyebabkan penurunan prestasi belajar siswa.

Salah satu usaha yang dapat dilakukan adalah menerapkan metode pembelajaran yang bertujuan mengaktifkan siswa yaitu supaya siswa mau bertanya tentang materi yang sedang dipelajari terlebih dahulu kepada teman sekelompoknya, bersemangat untuk mengerjakan latihan serta mempunyai rasa tanggung jawab dengan tugas dan kelompoknya. Maka perlu digunakan pembelajaran kooperatif. Saat ini metode pembelajaran kooperatif semakin berkembang. Salah satu tipe dalam pembelajaran kooperatif yang yang dapat digunakan adalah tipe True or False (Benar atau Salah). Zaini (2007:24) Pembelajaran kooperatif tipe True or False dapat membuat siswa terlibat secara langsung dengan materi. Selain itu pembelajaran kooperatif dengan tipe True or False akan membuat siswa lebih teliti dalam mempelajari materi.

Oleh sebab itu peneliti tertarik ingin melakukan suatu penelitian tindakan sebagai upaya dalam melakukan perbaikan terhadap pembelajaran dengan judul:" Penerapan Metode True or False untuk Meningkatkan Hasil Belajar Matematika Siswa Kelas VIII.7 SMP Negeri 21 Pekanbaru".

\section{METODE}

Penelitian tindakan kelas ini dilaksanakan di SMP Negeri 21 Pekanbaru. Penelitian ini dilakukan dalam beberapa siklus dan tiap siklus dilakukan dalam dua kali pertemuan. Sebagai subjek dalam penelitian ini adalah siswa kelas VIII.7 tahun pelajaran 2017-2017 dengan jumlah siswa sebanyak 39 orang.

\section{Variabel Penelitian}

Penelitian ini terdiri dari dua variabel yaitu:

1) Penerapan metode True or false merupakan variabel tindakan, yang dilihat dari observasi aktivitas guru dan siswa.

2) Hasil belajar merupakan variabel masalah, merupakan nilai atau skor yang diperoleh siswa melalui tes hasil belajar yang dilaksanakan pada akhir setiap siklus.

\section{Rencana Tindakan}

Objek penelitian tindakan kelas adalah meningkatkan hasil belajar Matematika pada siswa kelas VIII.7 SMP Negeri 21 Pekanbaru. Penelitian ini dilakukan pada bulan Februari 2017. Penelitian ini terdiri dari dua siklus. Adapun setiap siklus dilakukan dalam dua kali pertemuan. Hal ini dimaksudkan agar siswa dan guru dapat beradaptasi dengan metode pembelajaran yang diteliti. Sehingga hasil penelitian tindakan kelas dapat dimanfaatkan dalam proses belajar mengajar selanjutnya.

\section{Siklus Penelitian}

Berdasarkan jenisnya, maka penelitian ini tergolong Penelitian Tindakan Kelas (PTK). Sebagaimana dikemukakan oleh Arikunto (2006:16) bahwa penelitian tindakan kelas (PTK) adalah penelitian yang dilakukan dikelas dengan tujuan memperbaiki atau meningkatkan mutu praktik pembelajaran. Tindakan kelas yang diberikan pada penelitian ini adalah penerapan metode True or false dalam rangka meningkatkan hasil belajar Matematika siswa.

Penelitian ini dilakukan dalam beberapa siklus dimana tiap siklus terdiri dari tiga kali pertemuan, daur siklus penelitian tindakan kelas (PTK) menurut Arikunto (2006:60) adalah sebagai berikut

a. Merencanakan : Rencana tindakan kelas "Apa" yang akan dilakukan untuk memperbaiki, meningkatkan atau perubahan tingkah laku dan sikap sebagai solusi.

b. Tindakan : Apa yang harus dilakukan oleh guru atau peneliti sebagai upaya perbaikan, peningkatan atau perubahan yang diinginkan. Pada tahap ini rancangan strategi dan skenario penerapan pembelajaran akan diterapkan. Skenario dari tindakan harus dilaksanakan dengan baik dan wajar. 
c. Mengamati: Mengamati hasil atau dampak dari tindakan yang dilaksanakan atau dikenakan terhadap siswa. Tujuannya untuk mengetahui kualitas pelaksanaan tindakan. Peneliti melibatkan teman sejawat sebagai pengamat untuk melakukan pengamatan dan mencatat semua hal yang diperlukan dan terjadi selama pelaksanaan tindakan berlangsung.

d. Refleksi : Peneliti mengkaji, melihat dan mempertimbangkan atas hasil atau dampak dari tindakan dari berbagai kriteria. Tujuannya adalah mengetahui kekuatan dan kelemahan dari tindakan yang dilakukan untuk dapat diperbaiki pada siklus berikutnya. Jika terdapat masalah dari proses refleksi maka dilakukan proses pengkajian ulang melalui siklus berikutnya yang meliputi kegiatan: perencanaan ulang, tindakan ulang, dan pengamatan ulang sehingga permasalahan dapat teratasi.

\section{Data dan Cara Pengumpulan}

Adapun data yang akan dikumpulkan dalam penelitian ini adalah:

1) Data tentang penerapan metode True or false, yaitu data tentang aktivitas guru dan aktivitas siswa dalam pelaksanaan pembelajaran diperoleh melalui lembar observasi

2) Hasil belajar siswa diperoleh melalui tes hasil belajar yang dilaksanakan pada akhir pembelajaran tiap siklus.

\section{Indikator Kinerja}

Penelitian ini dikatakan berhasil apabila siswa yang memiliki hasil belajar yang tinggi (71 - 85) di dalam belajar Matematika dengan menggunakan metode True or False mencapai 75\%. (Wardani, 2004:4.21).

\section{Analisis Data}

1. Hasil belajar siswa

Adapun untuk mengetahui hasil belajar siswa dengan menggunakan rentang nilai yang dikemukakan oleh Gimin dkk (2008:20) yakni sebagai berikut:

Tabel 3. 1.

Disitribusi Hasil Belajar Mata pelajaran Matematika

\begin{tabular}{|c|c|c|}
\hline NO & Klasifikasi & Standar \\
\hline 1 & Sangat tinggi & $>85$ \\
\hline 2 & Tinggi & $71-85$ \\
\hline 3 & Sedang & $56-70$ \\
\hline 4 & Rendah & $41-55$ \\
\hline
\end{tabular}

Sumber: Gimin (2008:20)

\section{Implementasi Tindakan}

Penelitian ini terdiri dari dua siklus. Adapun setiap siklus dilakukan dalam dua pertemuan. Tiap siklus terdiri dari langkah-langkah perencanaan/persiapan tindakan, pelaksanaan tindakan, observasi dan refleksi. Setelah hasil pada siklus I diperoleh dan telah direfleksi selanjunya dilakukan perbaikan untuk melanjutkan ke siklus berikutnya.

\section{HASIL DAN PEMBAHASAN}

Setelah dilakukan penelitian pada siklus I aktivitas guru mendapat skor 35 dengan kategori sempurna namun terjadi peningkatan pada siklus II menjadi 49 dengan kategori sangat sempurna. Pada siklus I aktivitas siswa mendapat skor 226 dengan kategori tinggi meningkat menjadi 309 pada siklus II menjadi dengan kategori sangat tinggi.

Penerapan metode True or False mampu meningkatkan hasil belajar Matematika siswa kelas VIII.7 SMP Negeri 21 Pekanbaru . Meskipun pada siklus pertama aktivitas guru hanya berkategori sempurna, namun perbaikan pembelajaran yang dibawakan guru mampu meningkatkan aktivitas guru dengan penilaian sangat sempurna pada siklus kedua. Hasil ini berdampak positif terhadap aktivitas siswa, sehingga diikuti oleh hasil belajar mereka dalam mengikuti pembelajaran. Pada siklus I hasil belajar mendapat skor dengan rata-rata 72,6 (ketuntasan klasikal 69,23\%) dengan kategori tinggi 
namun demikian penelitian belum berhasil dan dilanjutkan ke siklus II. Pada siklus II meningkat dengan rata-rata 85,1 (ketuntasan klasikal 100\%) dengan kategori sangat tinggi dengan demikian penelitian berhasil pada siklus II, sehingga penelitian ini harus dihentikan karena telah melebihi persentase ketuntasan atau indikator keberhasilan yaitu $75 \%$.

Tabel 1. Rekapitulasi Hasil Belajar Siklus I dan Siklus II

\begin{tabular}{|l|c|c|}
\hline \multirow{2}{*}{ Klasifikasi Nilai } & Siklus I & Siklus II \\
\cline { 2 - 3 } & Jumlah & Jumlah \\
\hline Sangat tinggi & 2 & 12 \\
\hline Tinggi & 15 & 27 \\
\hline Sedang & 22 & 0 \\
\hline Rendah & 0 & 0 \\
\hline Rata-Rata Hasil belajar & 72.6 & 85.1 \\
\hline Kategori & Tinggi & Sangat Tinggi \\
\hline
\end{tabular}

Hasil belajar siswa pada siklus pertama dikategorikan tinggi, tetapi hasil belajar siswa lebih mengalami peningkatan dari siklus I ke siklus II. Hal ini juga dapat dilihat dalam histogram di bawah ini.

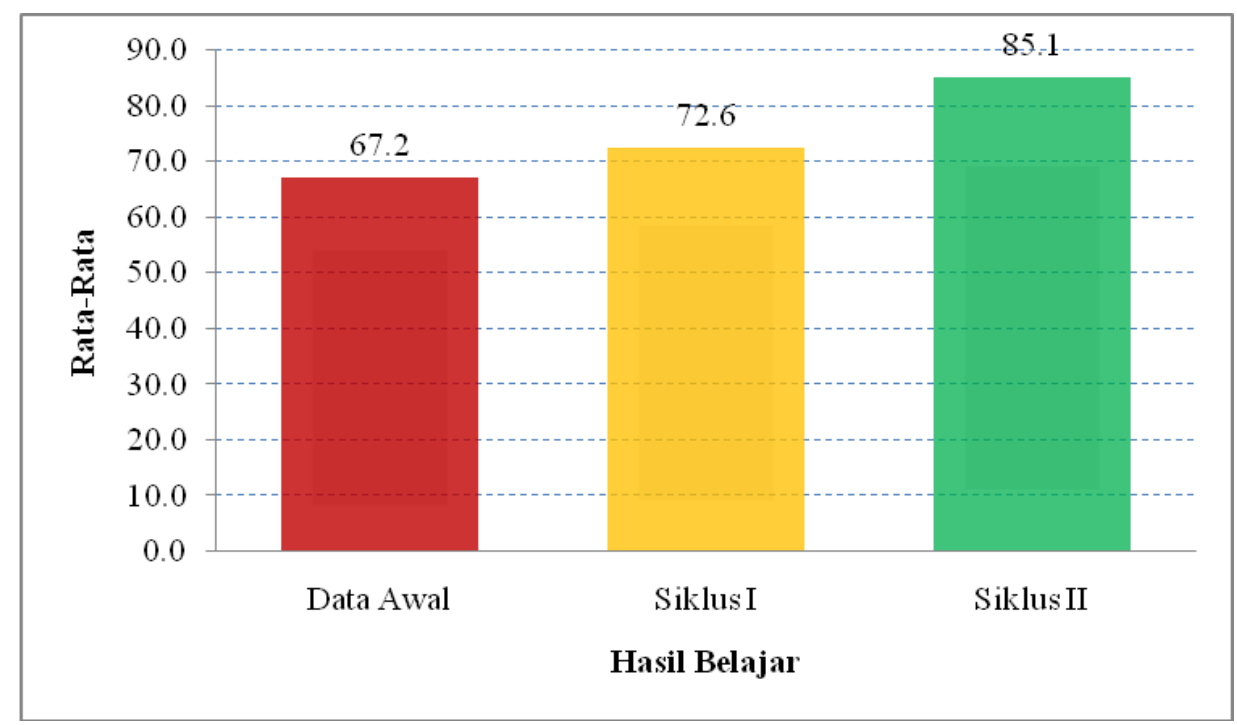

Gambar 4.1. Histogram Hasil Belajar Siklus I dan II

Histogram batang di atas menunjukkan pada data awal hasil belajar siswa hanya dengan ratarata 67.2. Siklus I hasil belajar siswa mencapai rata-rata 72.6 dan pada siklus II rata-rata hasil belajar siswa adalah 85.1. Hal ini membuktikan bahwa metode True or False dapat meningkatkan hasil belajar siswa kelas VIII.7 SMP Negeri 21 Pekanbaru .

\section{KESIMPULAN}

Berdasarkan hasil penelitian dan pembahasan, maka penerapan metode True or False dapat meningkatkan hasil belajar siswa kelas VIII.7 SMP Negeri 21 Pekanbaru. Untuk jelasnya dapat dilihat pada uraian berikut ini :

1. Aktivitas guru pada siklus I mendapat skor 35 dengan kategori sempurna sedangkan pada siklus II mendapat skor 49 dengan kategori sangat sempurna.

2. Aktivitas siswa pada siklus I mendapat skor 226 dengan kategori tinggi sedangkan pada siklus II mendapat skor 309 dengan kategori sangat tinggi.

3. Hasil belajar siswa pada siklus I mendapat rata-rata 72.6 dengan kategori tinggi sedangkan pada siklus II mendapat rata-rata 85.1 dengan kategori sangat tinggi. 
4. Pada siklus I ini belum dikatakan tuntas sedangkan pada siklus II penelitian telah tuntas atau berhasil dengan indikator keberhasilan 100\% melebihi indikator kinerja yang telah ditetapkan yaitu $75 \%$.

Sehingga hipotesis penelitian yang berbunyi "Penerapan metode True or False dapat meningkatkan hasil belajar Matematika siswa Kelas VIII.7 SMP Negeri 21 Pekanbaru dapat diterima.

\section{SARAN} berikut:

Ditinjau dari pembahasan dan kesimpulan di atas maka peneliti mengajukan saran sebagai

1. Agar pembelajaran True or False dapat berjalan dengan baik, maka sebaiknya guru dapat menerapkannya dalam proses pembelajaran, khususnya mata pelajaran Matematika.

2. Guru perlu melakukan upaya-upaya guna mempertahankan hasil belajar, agar tujuan dari pembelajaran dapat tercapai secara optimal.

3. Peneliti berikutnya dapat mengangkat metode-metode pembelajaran lain yang dapat meningkatkan hasil belajar siswa.

\section{DAFTAR PUSTAKA}

[1] Arikunto, Suharsimi, dkk, 2006, Penelitian Tindakan Kelas. Bumi Aksara : Jakarta.

[2] Ahmadi, Abu dan Joko Tri Pasetya. 2005. Strategi Belajar Mengajar. Pustaka Setia. Bandung.

[3] Gimin. 2001. Instrumen dan Pelaporan Hasil Penelitian Tindakan Kelas. Pekanbaru. Makalah Pelatihan Pelaksanaan dan Pelaporan Penelitian Tindakan Kelas.

[4] Hisyam Zaini, dkk, Strategi Pembelajaran Aktif, Yogyakarta: CTSD, 2007

[5] Melvin L. Silberman. 2006. Active Learning. Bandung. Nusamedia

[6] Muhibbin Syah. 1996. Psikologi Pendidikan. Bandung. Remaja Rosda Karya

[7] Roestiyah. 2001. Strategi Belajar Mengajar. Jakarta: Rineka Cipta.

[8] Sardiman. 2004. Interaksi dan Motivasi Belajar Mengajar. Jakarta. Rajawali pers

[9] Sanjaya, Wina. 2007. Strategi Pembelajaran Berorientasi Standar Proses Pendidikan. Kencana, Jakarta.

[10] Slameto. 2003. Belajar Dan Faktor-Faktor Yang Mempengaruhinya. Jakarta. Rineka Cipta

[11] Sudjana, Nana. 2005. Dasar-Dasar Proses Belajar Mengajar. Sinar Baru Algensindo. Bandung.

[12] Syaiful Bahri Djamarah. 2002. Psikologi Belajar. Jakarta. Rineka Cipta. 